\title{
Appropriation and rationality in hip hop groups organization practices in Porto Alegre: an analysis on the perspective of Guerreiro Ramos ${ }^{1}$
}

\section{Apropriação e racionalidade nas práticas organizativas de grupos de hip hop em Porto Alegre: uma análise desde a perspectiva de Guerreiro Ramos}

\author{
Guilherme Dornelas Camara ${ }^{2}$ \\ Sueli Goulart ${ }^{3}$ \\ Rafaela Mendes Reinher ${ }^{4}$
}

\begin{abstract}
This paper discusses the organizational practices of hip hop groups from Porto Alegre, southern Brazil, as they appropriate foreign experience and rationally guide their social action. The aim of this work is to investigate these practices, based on the formulations of Brazilian sociologist Alberto Guerreiro Ramos, as they are enunciated in the works The Sociological Reduction and The New Science of Organizations. This approach offers fruitful material to broaden the theory and may be subsidiary to this kind of socio-cultural study, explaining why it is pertinent in this field. In this sense, the hip hop movement can be viewed as valuable when it comes to understanding phenomena which, due to (and in spite of) being originally transnational, or even "foreign", act or interact worldwide. Examining the organization practices and social action of these groups also helped identify a concern with the production of cultural artifacts that represent and form a symbolism that is historically and culturally located. Another issue that was broached concerns the market since for those groups it is not a category absent from their struggles and actions, but the economic criteria are incidental in relation to their members' motivation.
\end{abstract}

Keywords: hip hop, sociological reduction, social systems delimitation theory, organizational studies

\section{Resumo}

Este artigo discute as práticas de organização de grupos de hip hop de Porto Alegre, no sul do Brasil, à medida que se apropriam da experiência estrangeira e racionalmente guiam a sua ação social. Os autores propõem a investigação das práticas com base nas formulações do sociólogo brasileiro Alberto Guerreiro Ramos, como enunciadas nas obras: $A$ Redução Sociológica e A Nova Ciência das Organizações. Tal abordagem oferece matéria fecunda para a teoria e pode ser subsidiária para este tipo de estudo sociocultural, explicando a sua pertinência na área. Nesse sentido, o movimento hip hop pode ser tomado como um objeto valioso para a compreensão dos fenômenos que, em virtude de (e apesar de) serem originalmente transnacionais, ou mesmo "estrangeiros", agem e interagem mundialmente. A análise das práticas organizacionais e a ação social desses grupos tornaram possível também a identificação de uma preocupação com a produção de artefatos culturais, que representam e formam uma simbologia que é histórica e culturalmente situada. Outro tema abordado diz respeito ao mercado, pois, para esses grupos, ele não é uma categoria ausente em suas lutas e ações, no entanto os critérios econômicos são incidentais em relação à motivação dos seus membros.

Palavras-chave: hip hop, redução sociológica, teoria da delimitação dos sistemas sociais, estudos organizacionais.

\footnotetext{
Paper received in April 2010 and accepted for publication in June 2010.

${ }^{1}$ This paper is part of results of the research project "Estratégias de participação e articulações organizativas na ação discursiva do Movimento Hip Hop nas cidades do Recife (PE) e de Porto Alegre (RS)", funded by CNPq via edict n. 003/2009.

2 Doctor and Master in Business - Program Post-Graduation in Business from Universidade Federal do Rio Grande do Sul (UFRGS) in the field Organizations / PPGA/EA/UFRGS. Address: Washington Luiz, 855, Porto Alegre, RS. E-mail: gdcamara@ea.ufrgs.br.

${ }^{3}$ Doctor in Business of Universidade Federal de Pernambuco. Deputy professor of Business School (Universidade Federal do Rio Grande do Sul UFRGS) in the field Organizations/ PPGA/EA/UFRGS. Address: Washington Luiz, 855, Porto Alegre, RS. E-mail: sueligoulart@gmail.com .

${ }^{4}$ Student of graduation in Business of Universidade Federal do Rio Grande do Sul ( EA/UFRGS). Address: Washington Luiz, 855, Porto Alegre, RS. Email: rafinha_mr@hotmail.com .
} 


\section{Introduction}

The rich Weberian description of society's modernization process, particularly centered in the rationality that guides social actions, sustains the argument of society's increasing bureaucratization since the beginning of the $20^{\text {th }}$ Century. Invading all social relation spaces, there has been a prevalence of what Weber has described as "means-end rational actions", i.e., individuals, in their social relations, use adequate means for a determined purpose. Their expectations are guided to external objects and other human beings as 'conditions' or 'means' to achieve, as a result, the attainment of their own intentions, which are rationally pursued and calculated (WEBER, 1994).

In the field of organizational studies, the Weberian description has long been influenced by the Parsonian interpretation which, as it introduced Weber's works into the United States, has led to a functionalist-systemic approach, determining the need for a perfect fitting of organizations and individuals into social systems. This approach was designed to provide and maintain order, according to dominant presuppositions about the contents of what's established as "order." This guideline's prevalence has stood, among others, on a tautological methodology, i.e., because functional organizations were studied, their formulations were reproduced; such formulations consolidate the theoretical framework which in turn can only contribute to illuminate aspects of those very organizational formations.

Arguments about the inadequacy of studies on other existing organizational forms and processes have been extensively refuted, since Frankfurt critical theorists, and also more recently in our field of studies. In relation to having social movements as study objects, we resort to the arguments by Misoczky, Flores and Goulart (2008) about the pertinence of studying social movements in the Organizational Studies. Among other reasons, such movements "develop processes, organize, deliberate, produce territory in the most diverse ways and even build structures, there's no denying they constitute social organization practices." They may not do it under guidance of the dominant structural-functionalist stream and, for this very reason, they can offer a fertile field for theoretical widening and sociocultural pertinence to the studies in the area.

Therefore we conceive that these movements' very social research should be liberated from structuralfunctionalist restraint, as "the organization theory's success, based on the functional rationality inherent to the social science dominant in the West, has been one-dimensional and [...] it has a disfiguring impact over the associated human life". Thus, we share Guerreiro Ramos' position that "the interest that guides research of a critical theory of society is man's emancipation through developing his self-reflection potentialities' (GUERREIRO RAMOS, 1981, p.12).

Based on the reflections of this sociologist from Bahia, we consider it necessary to break up with the majority of applied social sciences' traditional configuration as well as with the way they have been approached, as "[the] established social science is also founded on a functional rationality, one that is particularly characteristic of the market system" since "in the social domain, erroneous epistemological premises become a cryptopolitical phenomenon - i.e., a disguised normative dimension imposed by the established power configuration" (GUERREIRO RAMOS, 1981, p.2).

In this paper, we propose to investigate the organization practices in Hip Hop movement groups in Porto Alegre, from the perspective of Brazilian sociologist Alberto Guerreiro Ramos' formulations, enunciated in the works "A redução sociológica" (The sociological reduction), and "A nova ciência das organizações" (The new science of organizations). We consider it relevant to carefully study this important Brazilian intellectual, whose theoretical consistency is ever contemporary to Brazilian social reality, and may, therefore, contribute to understand the current phenomena, while naturally respecting the necessary contexts.

Some aspects of the research must be pointed out in order to make clear our position as researchers and our involvement with the investigation. The data gathered to this paper have been obtained through observation techniques in some hip hop events, documentary collection and interviews with rappers Hantaru, Mano Oxi and members of Grupo Revolução RS (and Ksulo, their self-designated NGO). Photos, songs, lyrics, videos and 
graffiti were also helpful to support our analysis. The data collected were interpretatively analyzed along with the theoretical references, in a qualitative research approach.

This paper is organized as follows: in section 2 we present the hip hop context in Porto Alegre. Concomitant to it we introduce the methodological character of Guerreiro Ramos (1996) formulations on Sociological Reduction. In section 3 we approach the Social Systems' Delimitation Theory (thus designated by the author himself, 1981), highlighting its proposing charge, more than being merely capable of explaining social reality. There we will resort to the theory as an analytical support simultaneously to data presenting, so as to build a summarized account, though one which explores the author's theoretical as well as the groups' experience richness. Finally, in section 4, we make some remarks about the experience of hip hop groups in Porto Alegre, though in a non-conclusive fashion.

\section{On hip hop context in Porto Alegre: group genesis and local reality appropriation}

The hip hop movement in Brazil had its genesis between the late 1970's and the early 1980's, in the wake of the main period of black parties, which instilled race pride and conscience and, therefore, new attitudes, particularly among the youngest parts of the population of African descent (RIBEIRO, 2007).

Even though the movement's first influences have come to us through the phonographic industry or brought over in the luggage of Brazilian tourists traveling to the United States, birthplace of the movement, hip hop was very rapidly spread and assimilated among young people in the poor suburbs of Brazilian cities. That proximity is due to the amount of exclusion, fight and resistance that has marked the movement since its origins in the Bronx area, in New York City.

There, in the late 1960's, hip hop came along as an alternative to rebuild the black identity based on race union and pride. According to Leão (2006, p. 5), one of hip hop's central elements - break -

is the recovery of several cultures, like Brazilian capoeira, eastern martial arts, mimics, American tap dancing and Indian dance. This fusion of body expressions opened a huge space of proximity to various ethnically different groups.

Break was the first hip hop element to become popular in Brazil for being similar to the existing practices in the funk and soul parties that used to take place in the poor suburbs of São Paulo still in the 1970's. The black parties - as funk and soul ones were previously identified - made it possible for hip hop to get to the suburbs of Porto Alegre in the 1980's. The other elements of hip hop such as rap, parties conducted by a disc-jockey (DJ), the singing of masters of ceremony (MCs), and graffiti rapidly spread the movement's message. They used to (and still do so) appeal to young people from the poor miscigenous suburbs of Brazilian cities which, like Bronx in the 1960's, are frequently identified with violence, dirtiness, segregation and social exclusion.

Since it has a specific locus - the cities' suburbs - hip hop assumes also characteristics of a movement of resistance and affirmation of both ethnicity and citizenship and, moreover, it disseminates among young people, which is most attracted to the goods offered in the official market, and to the drugs and violence provided by unofficial market. Through that locus, the young invade the cities' cultural scene and build

a sociocultural phenomenon in which, as they reject the seduction of the 'fool's gold' offered by behavior vogue-producing phonographic industry's monopoly [...] they organize themselves in possessions ${ }^{l}$ throughout Brazil, and they hold studies and events, produce art, interfere in language and education methodology, independence, authenticity, attitude. (FAUSTINO, 2001, p.10)

While discussions persist about hip hop being characterized as a social, cultural or street movement (ROCHA; DOMENICH; CASSEANO, 2001), the fact is that a social action is already identified. It's performed at the impulse of certain self-appreciation ideological parameters in the black descent youth, through a consistent refusal of violence and outcast stigmas. And it is fairly likely that through the elements that form the movements, new practices in organizing collective action for identity affirmation and participation are arising, 
unavoidably in connection with other social actors. And that starts with its centrality both in language and local interaction in their actions, in spite of its elements' transnational character.

While he discoursed about movement innovations arisen in the transition from the Brazilian military regimen period to the country's (re)democratization, Paoli (1991, p.115) thus characterizes them:

the subject(s) that contemporary culture stages is another one: it's one who reclaims the sense of his experiences such as the experience in specific meaning attribution practices; he's willing to assume his own decentralization, the localism of the space he acts in, his action's immediate character; in one word [...] self-referenced, self-establishing subjects in his world, of his differences and similarities, of his identities and alterities.

It appears to us Paoli's (1991) characterization represents well the action of hip hop groups, whose main weapon is the word, which supports cultural, artistic activities and is at the same time a resource that has led young people to reflect on their reality and to attempt to change it (ANDRADE, 1999).

Likewise, it refers us to the idea of Sociological Reduction, which, because of its praxiological dimension, adds up to the "knowledge imperative", ruled by a "methodic attitude", a "social need of a community that, in fulfilling its historic existence project, has used other communities' experience" (GUERREIRO RAMOS, 1996, p.81-82, italics in the original).

In that sense, hip hop movement can be taken as a valuable object for us to understand phenomena which, in virtue of (and despite) being originally transnational, or even "foreign", perform territorially placed actions an interactions. We were able to observe this across hip hop groups in Rio Grande do Sul, where the movement arrived in the mid 1980's.

The process through which the movement was approached took place from funk and soul parties and then moved on into the streets. The first break dance gatherings took place at Esquina Democrática (where Rua dos Andradas and Avenida Borges de Medeiros meet, in downtown Porto Alegre), in 1983. Since the early 2000's, break dance gatherings began to take place weekly at Praça da Alfândega, also in downtown Porto Alegre (FIALHO, 2003). As in São Paulo, graffiti arrived in Rio Grande do Sul (RS) almost simultaneously to break dancing. Some graffiti painters stood out, like Trabalho ou Trampo, who participated in the project "Global Mural" in 2000, when seventy graffiti works were made in five continents (FIALHO, 2003).

Rap is the hip hop element with the largest expression in the state. As estimated by TV show Hip Hop Sul, broadcasted by Rio Grande do Sul's public TV station - TVE - and referred to in Fialho's (2003) research, there are about five hundred hip hop groups in RS, and Da Guedes group is the best known nationally. Rapper Piá, who hosts a show that broadcasts black music on Ipanema FM radio, (belonging to a media group called Bandeirantes), is also fairly well known in the scene and has performed in Rio de Janeiro and São Paulo, as well as Hantaru and his group, Attack Frontal, who have performed with Thaíde and the Racionais MCs, both of whom are great national hip hop icons.

The large number of groups suggests an intense pursuit for expression mechanisms and vehicles and, as we were able to discover from the interviews, a necessity to give an account of their community's reality, building and establishing local codes that have plenty of meanings for the groups themselves as well as their communities, i.e., they're locally referenced. At the same time, hearing and identifying their own life stories, and those of their neighborhood, has made many young people start making rhymes, as Hantaru told us:

At about eight years old, I started to listen to hip hop and noticed that police beat up poor, darkskinned guys. That his place was like mine, and then I started to identify to that. It's a way for a guy to let his anger out in a healthy way, so I started writing and participating in festivals. I was doing well and things went on...

...What awoke me was lyrics with a social sense... 
The significant number of groups, as well as their strong action in urban centers, has also created formal spaces for appreciation of their works at both municipal and state levels, as was the case with the passing of Municipal Act 10.378/08, which created the Semana Municipal do Hip Hop (City Hip Hop Week) as part of the city's official event calendar; it is scheduled to take place each year in the second week of May, in Porto Alegre. During the Week, "divulgation is to be made about works performed in the several art forms that are characteristic of 'hip hop' movement, such as 'break,' graffiti, 'rap,' among other art forms that are representative of the movement". The Act establishes that "civil society, through its organized Hip Hop Movement representatives" is to integrate the Week's organization committee (PORTO ALEGRE, 2008). In September 2008, the Week was extended to the whole state, through the passing of Act 13.043/08 (RIO GRANDE DO SUL, 2008).

The result of intense rallying by hip hop movement members and militants, the Act's passing was celebrated during the $1^{\circ}$ Encontro Estadual do Hip Hop ( $1^{\text {st }}$ State Hip Hop Meeting), held in June 2009, with a large attendance, as can be seen from the pictures below.

The way expression occurs within the movement contributes to reduce, in Guerreiro Ramos's (1996) terms, foreign hip hop's reality to national context and, above all, to a local context. Groups act politically due to the social need of their specific communities which, while executing their historic existence project, use critical assimilation of the foreign experiences. Therefore, there doesn't seem to be an adherence to a foreign hip hop model, as local reality is incorporated to music, so discourse practices are re-contextualized and thus resignified.

\section{Picture 1: Board formed during the $1^{\circ}$ Encontro Estadual de Hip Hop ( ${ }^{\text {st }}$ State Hip Hop Meeting), in Porto Alegre, 2008.}



Photo by the authors 
Picture 2: The public attending the $1^{\circ}$ Encontro Estadual de Hip Hop ( ${ }^{\text {st }}$ State Hip Hop Meeting), in Porto Alegre, 2008.

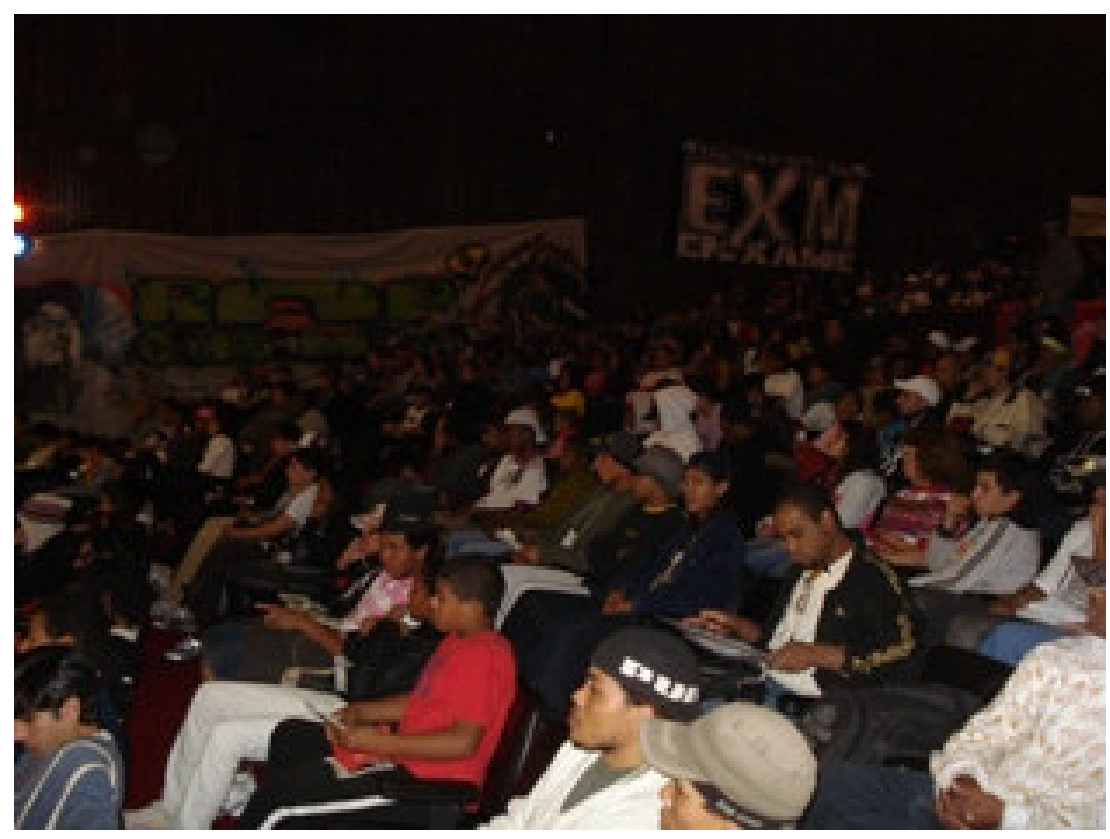

Photo by the authors

Picture 3: The public attending the $1^{\circ}$ Encontro Estadual de Hip Hop $\left(1^{\text {st }}\right.$ State Hip Hop Meeting), in Porto Alegre, 2008.

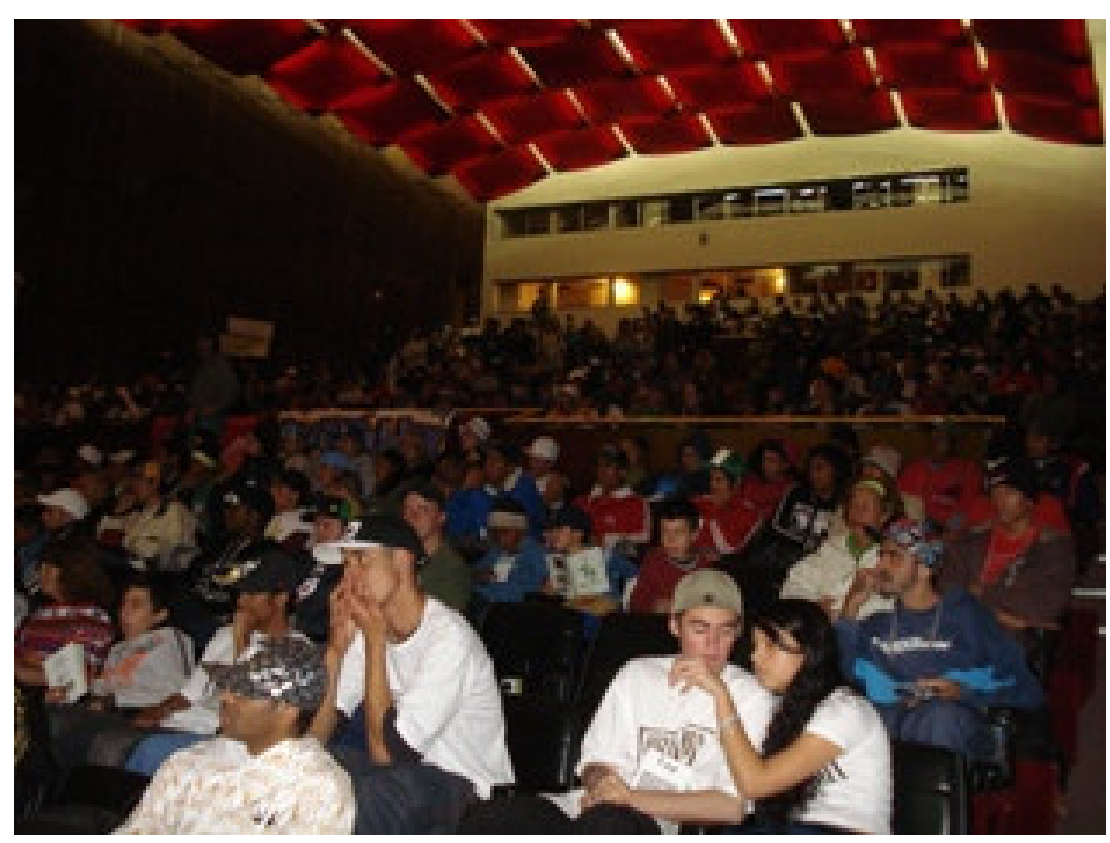

Photo by the authors 
Hip hop group protesting, fighting expression is performed through discourse, i.e., in the denouncing contents of lyrics bearing a social, political mark. Here we find the movement's genesis, since it is impossible to conceive it outside a totality of social relations established upon a specific historic time and in a certain space. When we refer to discourse action, we assume that all the elements related to social actors which represent processes of communication with reality are interpreted as discourses, and such discourses should be understood from the context they were generated in. As a cultural element, a discourse cannot be understood without its original situation's contextualization (OUTHWAITE; BOTTOMORE, 1996).

The poor suburbs' representation in the songs cannot be thought about out of suburbs' very place, even when the movement's discourse goes beyond such limits. Due to its historic dimension, the locus doubtlessly causes traits in both individuals' and hip hop groups' own identities, as one can see from Hantaru's assertions already previously presented.

Identification between the lives of young people in the poor suburbs and hip hop elements have also a strong racial trait. Another hip hop group member, cultural activist Mano Oxi, emphasizes what he calls "hip hop's African aspect". He highlights hip hop's "beat" referred to drums, and the typical "spoken singing" of songs as a mark of African culture's orality.

What we were able to observe from the interviews, the State Meeting, TVE shows and from local newspapers is that hip hop groups have been placing themselves into several cultural and education activities in the state, such as the performance of rap and graffiti workshops in prisons, municipal schools etc. Groups seem to have found a space for their cultural, political, artistic expression as well as for their members' survival. Besides acting in hip hop groups, they also form or adhere to non-government organizations (NGOs) in order to design and execute projects; they create businesses to produce and sell clothes, CDs, gigs etc. Some also work as advisers to congressmen, linking groups, communities and representatives. Through that activity, they've been able to get groups' subjects of interest into the agendas of city and state government, as with the Acts referred above.

If it's true that such groups' dynamics, claims, aesthetics, rhythmic requirements and, above all, emphasis on hip hop essential elements (break, rap and graffiti) keep the North American reference, it's also a fact that they elucidate existing ideological divergences between movements in the two countries.

While in the United States groups have been incorporating market elements into music, such as individuality praise, consumer goods possession and financial gain, the ideological mark that characterizes the protesting discourse is visibly fading away, but for a group called Public Enemy and 2 PAC duo, as exceptions. In contrast, most groups from Porto Alegre still show a denouncing attitude and attempts to change people's living condition in the poor suburbs, exposing the political foundations of their social action.

For that reason, Porto Alegre hip hop group action refers us to the notion of sociological reduction, formulated by Guerreiro Ramos in 1958, who has presented it as a method that's based on: 1) foreign sociological production's critical assimilation; 2) a parenthetical attitude that allows individual to transcend as much as possible the circumstantial conditioning that conspires against his free, autonomous expression; and 3) overcoming the sociology that's based only on the reproduction of concepts in university environments (GUERREIRO RAMOS, 1996). Thus, sociological reduction converts sociology's universal, noncritical model into an assimilating-critical attitude.

Those formulations seem to us very present in the groups we've had contact with and from the data we have collected. The distancing between local group discourse practices in relation to their perception of what is currently occurring in the United States becomes evident when movement members affirm that

their lyrics have nothing to do with ours. Their lyrics talk only about money, diamonds, cars and women. When Ja Rule was here, I [Hantaru] talked to him. He told me that they even used to make protest Rap, but no one would listen. 
Once it's established that rap and graffiti are the means through which hip hop group discourse action is most disseminated, we stress the importance of the ethic-aesthetic indelible connection of their signifiers and signifieds, so as to undermine occasional content resignification efforts aiming at economic purposes, as was the case in the United States. Hip hop workshops in events - and in the most diverse places they occur constitute a way of broadcasting hip hop discourses at the same time they save the values which orient the groups' actions, respecting local particularities.

\section{A hip hop analysis from the perspective of the social systems' delimitation theory}

It's a fact that as we question about the types of rationality that have oriented hip hop movement group organization practices in Porto Alegre, we start from the four types of social action identified by Max Weber (1994, p.22), namely:

a) the rational action concerning the ends, "in virtue of an agreement between those interested or in virtue of imposition";

b) the rational action concerning values, i.e., "[in the] validity of what has been recognized as absolutely valid";

c) the action that has its validity from an affective belief, specially an emotional one, which is occurs through "that which is newly revealed or exemplary";

d) the action that succeeds in virtue of tradition, namely, the "validity of what has always been like this".

As Guerreiro Ramos (1981 p.38-39) critically analyzes the Weberian types of rationality, he affirms that the differentiation between the two rational action modes made by Weber needed considerations about "the irrational elements that disturb that conduct's yield or success." For this reason, the author refers to the appreciation of adjectives "functional" and "substantial", as defined by Karl Mannheim, to which he resorts to stress, respectively, the action gauged "in relation with a preset objective" and that which "attests human being's transcendence, his quality as a reason-gifted creature". The author clarifies that "substantial rationality is strictly related with the concern to keep freedom."

We conceive a priori that hip hop movement discourse action is not performed because of any tradition or because of a mere affective belief, considering that adhesion to the movement does not happen because of simple determinism or because of a transcendental identification that is unexplainable. Because they concern action, hip hop organization practices have human rational activity as its foundation, since they are conscious, voluntary and intentional. The analysis of the rationality which guides the groups' action is established on the purpose-value cleavage.

The reflection on rationally oriented organization practices of hip hop groups is not a mere taxonomy between functional and substantial rationality. It should be understood how such practices integrate the groups' action, thus accounting for the way of life they assume as a priority in their activities; i.e., it is not a matter of "measuring" how much functionality or substantiality can be found in their actions, but how such rationalities manifest themselves, and the space they occupy in their action and project routines.

In market-centered societies it is possible to recognize an attempt to enclose human life's totality, which doesn't leave the individual in general another option than giving up his own autonomy and his own interpretation of events. In this system, it is from functional rationality exacerbation that the very transvaluation of reason derives, i.e., human values become economic values and the constitution of associated human life, understood as a community of conscious, free women and men, becomes nonviable.

However, Weber (1994) had already stated that different types of rationality are simultaneously present in individuals' attitudes in social relations. But, as we have previously said, the tautological methodology has 
been leading to a "fixation" in one single type of rationality - functional or instrumental rationality. Therefore, we pursue to highlight hip hop group actions and processes which denote their substantive orientation.

Certain discourses, lyrics and graffiti represent what Guerreiro Ramos (1981) qualifies as intelligent perceptions of inter-relation events, in a certain situation. We illustrate this affirmation with a series of testimonies by group members.

Our argument that hip hop group actions in Porto Alegre have another foundation than the "utilitarian calculation of consequences", can be backed up by rapper PX, when he explains the beginning of Ksulo, a collective that designates itself a non-government organization - although it is not legally established as so:

Ksulo is, primarily, part of the idea of a group named Revolução RS [formed] by Bom Jesus inhabitants, of the need in their lyrics, which have always had a certain pinch of ideas, ideologies, attitude and somehow we was doing something else than singing and rhyming, which would be the need that we had, to be contributing to our community and our youths which was coming along, right?

PX's speech indicates the beginning of a discourse action which, on the creative exercise of singing and rhyming, connects with their own experiences within their own locus. That is, the facticity of life in the poor suburbs involves and connects discourse practices that lead to organization actions, which includes pursuing organization formal spaces. To illustrate: the NGO PX talks about is a constant "intention" of the group's members, who see it as the possibility to make projects viable and to formalize participation in public spaces. According to another member, since 2008 they were able, through an arrangement between Ksulo and the Lutheran Foundation of Deacon-ship, to develop silk-screen printing workshop projects for young people in the community. From a formal point of view, nothing is observed in relation with Ksulo, in spite of the group's efforts to legalize it. However, Ksulo is often referred to in events related with hip hop and city or state policies for young people.

Their involvement with Vila Bom Jesus community has also the purpose of strengthening inhabitants' identity and self-esteem. In mid 2008, a series of news reports on several media from Porto Alegre, among which Jornal Zero Hora - the largest newspaper by circulation statewide -, highlighted the violence in the area by criminal groups located there (ETCHICHURY, 2008). We highlight the report in which the state police commander-inchief announced:

We intend to stay here for about 15 days, 24 hours a day, in order to have control over what's happening. We'll make noise. [...] explained state police commanding officer, Colonel Paulo Roberto Mendes.

In order to mark territory, the police settled a camp within the neighborhood and pulled up their flag, as can be seen from the picture below. 


\section{Picture 4: Police camp (RS) in Vila Bom Jesus}

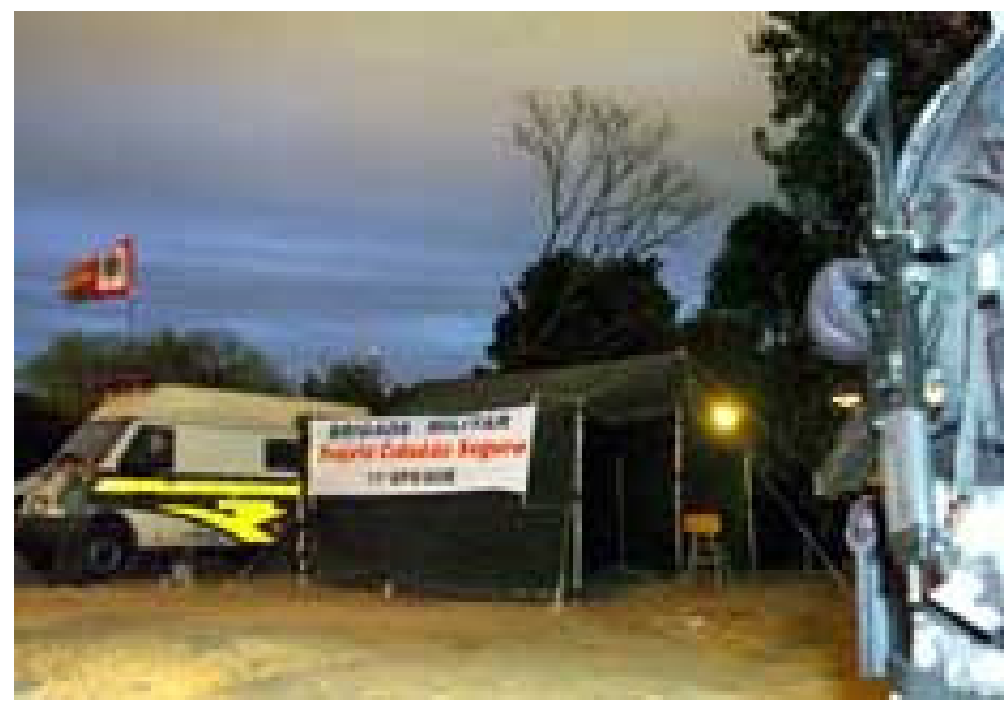

Photo by Cynthia Vanzella/Zero Hora

About one month later, members of Revolução RS group gathered with inhabitants from the neighborhood and chose one of the spots media reports referred most, in order to express through graffiti their resistance to weapon and traffic violence, which reaches the whole city (and not only that neighborhood), and to media prejudice, which marks inhabitants with violence- and drug dealing-related stigmas in a simplistic, fatalist view of reality. In a reference to the bus route that circulates through the neighborhood - route 470 - demonstrators wrote on a residence wall (with the dweller's permission) the sentence '470 urges Peace' illustrated with the figure of a young man with a Ksulo hat on, as can be seen from the following pictures.

\section{Picture 5: Graffiting on a residence wall in Vila Bom Jesus}



Photo by the authors 


\section{Picture 6: Graffiti in a wall in Vila Bom Jesus}

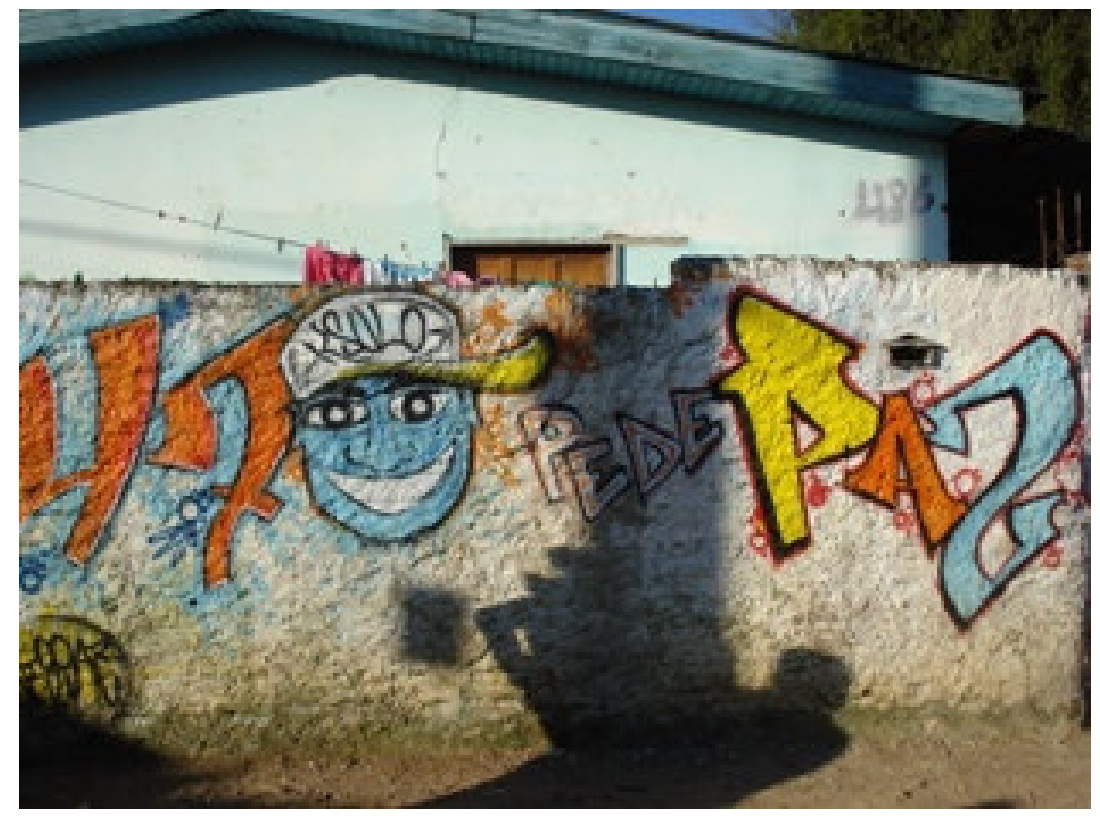

Photo by the authors

Assuming, from what was exposed, that the linking of individuals to a hip hop group is rational, it is possible to affirm that it's not based on pure utilitarian purposes, although both community recognition and income possibility through music or other hip hop-related activities are important. However, we reject the hypothesis that adhesion to hip hop is founded on a purely functional rationality, i.e., "determined by an expectation of results" (GUERREIRO RAMOS, 1981, p.5). In the artistic universe, particularly in Brazil today, musical activity, specially if performed by young people, very often implies adhesion to market mechanisms. It clearly has a strong impact on lyrics, attitudes and access of singers and composers to communication media.

It is certain that some hip hop groups participate in this "market", but their discourse action still directs to local and community concerns, even though they also pursue some means of economic support, even for individuals to be able to guard themselves from the ever present appeals of illegal activities.

Questioned about the commercial orientation of Porto Alegre hip hop groups, Hantaru says:

There's got be a commercial part, otherwise you'll starve, the guy who tells me he's not commercial, that's a lie. Whoever goes into a radio must have a song the guy from the radio will like, or else he's not going to play it.

However, he strongly affirms he wouldn't change his lyrics in order to sell:

No! I've had the opportunity to join hyped groups, make money, but I didn't want to change my lyrics. In my album there are several kinds of music, we try to make it mixed, but I say what I have to say. I talk about parties too, you laugh, you play, you have a girlfriend, but I'm not making an album that's only about parties either, after all, you can't lose the social side. The important thing is not to lose your origins, talk about the problems, talk about what the folks from your hoods want to hear.

One can see that the actions are obviously oriented towards different types of rationality, but one also realizes the prevalence of values orienting individuals' conduct. We infer that many of those principles come from the identification of a precarious collective situation, of the pursuit of prospects to leave a situation that's unfavorable in every way. 
Mano Oxi, who leads a group named DNA - Dinastia Negra Absoluta (Absolute Black Dinasty) -, affirms

in the poor suburbs, limitation to knowledge access (school, music classes etc) leads youths to get involved in drug trafficking and criminality.

He refers to his own story in order to illustrate what he says: at the age of fourteen he grabbed a gun, at 25 he became a traffic chief. And he adds:

who would I be, what would my future be? I've lost over 100 friends to crime, to prison.

Mano Oxi is now 33 and works at the State Congress in Rio Grande do Sul, as an advisor to state congressman Raul Carrion, providing support specially on themes related to youth and Afro-Brazilian culture besides, obviously, hip hop. He considers that hip hop provides the creation of a new character and that rap is the therapy for the marginalized; the poor suburbs' divan.

We realize that insertion in economic activities, to the leaders of groups we studied, is oriented towards attempting to open alternatives to young people in the poor suburbs, they're not the priority target in their actions, but a way to bypass people's survival difficulties. As Tiririca, who is responsible for developing hip hop activities in the Rubem Berta neighborhood, said:

within Porto Alegre's poor communities, people with great talents are raised and sometimes won't flourish due to a lack of opportunity. [...] Social work within Hip Hop... it's quite larger than dough. Only this thing of hip hop being able to go on inside a descent thing, the things it does, there has to be government support.

We stress that the economic dimension highlighted above places itself away from the economic character's expansion into all spheres of life, as propagated by the logic guiding the market system. Therefore, Porto Alegre hip hop movement groups get closer to Guerreiro Ramos' proposal for the Social Systems' Delimitation Theory.

With his theory, Guerreiro Ramos doesn't intend for individuals to take refuge in social micro-spaces, but to act in organizations of diversified natures instead, thus aiming at their self-actualization and the maintenance of the social systems they're engaged in. The paradigm the author proposes is a para-economic one, i.e., market is a legitimate, necessary social enclave, but a limited, regulated one in which "the purposes of human life are diverse and only few among them essentially belong to the sphere of formal economic organization" (GUERREIRO RAMOS, 1981, p.125). In order to achieve that multiplicity, a few conditions are necessary:

a) the limits of an organization should match its purposes. To Guerreiro Ramos (1981), economic organizations shouldn't cross the borders of their action, i.e., they can't acquire a social range that's wider than the economic sphere. Here, the author seems concerned with the increasing power of companies in contemporary society.

b) it's necessary for expectation on individual conduct in economic organizations to be reviewed because, Guerreiro Ramos (1981, p.135, italics in the original) considers, that "the administrative behavior is intrinsically embarrassing and incompatible with human potentialities' full development";

c) the economic organization is only a particular case of several types of micro social spaces, therefore it is necessary, in order to make real the multiplicity of centers, to look into the several existing types of organization.

d) human being has different kinds of needs whose satisfaction requires multiple types of social scenery, hence the necessity to multiply the guidelines of a theory of fact socially relevant.

Against the process of turning individuals into one-dimensional men, previously characterized, Guerreiro Ramos defends the need to formulate social systems concerned with human actualization, by means of a variety 
of organization environments that enable society to reach that objective. This means that such systems should not be reduced to the company's monolithic type: “[...]. The paradigm presented here shows that human actualization is a complex effort. It can never be undertaken within a single type of organization (GUERREIRO RAMOS, 1981, p.143).

As Guerreiro Ramos defends the creation of varied social systems as one of the subsidies to human actualization, he inaugurates a real possibility of action against the historic determination of life condition of socially excluded individuals. Therefore, it's not a matter of simply sheltering them in social micro-spaces, but qualitatively changing their historic condition existence. Such change is ensured by a multiplicity of social systems oriented towards their members' actualization. From that perspective, a few specific details of what Guerreiro Ramos calls para-economic paradigm are necessary. Instead of proclaiming total integration between individual objectives and organization targets, Guerreiro Ramos emphasizes an orientation towards both individual and community, i.e.,

In the social world viewed by the paradigm, there are places for an individual actualization that is free from imposed prescriptions, and that actualization can occur in small executive environments as well as in regular size communities. In those alternative places, a real personal choice is possible [...]. In that social space, the individual is not forced to conform entirely to market system values. He is given opportunities to occupy himself or even to outdo the market system, creating several social environments which differ from each other in nature, and participating in them. Altogether, the space portrayed by the pattern is one where the individual may have an adequate action, instead of behaving only in a way that matches expectations in a market-dominated social reality. (GUERREIRO RAMOS, 1981, p.141-142, italics in the original)

The space diversity the author preconizes in his social system delimitation theory presupposes that not only economies, but also organizations oriented towards their members' personal actualization are established in rules that ensure social system order, so that

in order for any work execution to be achieved, compliance with operation rules must exist. The larger the work's economic character, the less personal actualization opportunity is offered to those who execute it by their respective operational prescriptions. And that occurs because there is minimal opportunity for personal choice [...] That contradiction between individual needs and economic organization demands can't be solved through any behaviorist or so-called humanistic practice. Goods production and service rendering, under the cost-benefit liquid balance maximization imperative, require organization types in which there is obviously little tolerance for personal actualization. (GUERREIRO RAMOS, 1981, p.143-144)

In order to clarify the organization types the author preconizes, it is interesting to provide the concepts for the categories represented in the paradigm:

a) anomy and mutiny: the author provides the concept of anomy as an impervious situation, in which individuals are not provided with rules or roots, have no commitment to operation prescription and are incapable of shaping their lives according to a personal project. Anomic individuals aren't fit to create a social environment and obey prescriptions from organizations that are important to their subsistence. In such lack of relation with other individuals, mutiny refers to collectivities that are not provided with guiding rules and whose individuals lack a sense of social order.

b) economy: to Guerreiro Ramos (1981) an economy is a highly orderly social context which is established for goods production and/or service rendering. An economy's survival is based on its effectiveness, i.e., on profit and/or on the cost-benefit ratio. Other characteristics of this type of collectivity are: large dimensions in size; the fact that they are formed by employees; information control.

c) isonomy: Guerreiro Ramos provides the concept of isonomy as a context where all members are equal. By way of example, the author refers to the Aristotelian polis. Similarly to it, an isonomy 
has an ideal size, which allows its effectiveness. An isonomy is characterized by allowing its members' actualization, regardless of imposed prescriptions. An isonomy is self-gratifying, since its individuals associate freely and perform activities that are fulfilling for their own sake. Such activities are promoted as a calling, not as a job. In that type of system, still, there is no differentiation between leadership and subordinates, i.e. its decision making and guideline setting system is wide, thus constituting a community where authority is distributed by everyone's deliberation.

d) phenomy: the author provides this concept as an occasional social system, more or less stable, characterized by minimum subordination to operational prescription. In a phenomy, individuals have autonomy over their creativity and therefore strive only in self-motivated works. Guerreiro Ramos establishes that this type of social system is protected against market penetration. It defies the market system. One basic characteristic of a phenonomy is that, although they are interested in their own singularity, members don't lack social conscience.

e) the isolated: to Guerreiro Ramos, the isolated individual, as opposed to the anomic one, is the one to whom the social world is something uncontrollable and which can't be repaired. In spite of that belief, the isolated individual finds a space in the social fabric and so he lives adjusted to social patterns. Isolated individuals are often the nonparticipant employees and the citizens who systematically hide their personal convictions from other people. In such conditions, when individuals engage in an organization whose project is the personal actualization of its members, they break up with such historic determination and provide a reorganization of naturalized social relations.

The types of organizations categorized by Guerreiro Ramos brings in foundations to the analysis of the rationalities that beacon hip hop group discourse action. Ksulo perform works with young people from poor suburbs so as to integrate hip hop's four elements - rap, graffiti, DJ and b.boy. To PX, from Ksulo,

they are elements that, within their ghettos today, have developed a great social commitment. [...] And rap was one opportunity, I guess not only to me but to the other communities as well; a way for us to have today a certain autonomy in society. [...] many see rap today as a form of marginalization so to speak; to us, rap, hip hop, it has become an income source, a work source, better saying, and also a way for people to show one part of the culture, a culture that was often 'ghettoized' within these communities. Today, hip hop shows society that's not only that, it's not only a bunch of black folks trying to imitate or trying to show something that doesn't exist. In fact, today we rhyme the reality that goes on within poor suburbs in a way that today's society is amazed to learn the way folks are organized, the way we're organized. And to start making real hip hop, what we really need is an opportunity, from our need to be able to explore, to be able to divulge, to be able to happen.

What is evident from PX's discourse is that hip hop movement presents itself as an alternative to the marketoriented organizations' hegemonic project in effect. However, it wouldn't be proper to affirm that hip hop is rebelling against the market, whilst it is not pursuing its mere inclusion in it, since in a market-centered society, economies are free to shape its members' minds and its citizens' lives in general. So, "a market-centered politic and administration theory [...] assumes that the efficient performance criterion, in a mutual relation between individuals and economies, summarizes human nature completely" (GUERREIRO RAMOS, 1981, p.148).

In hip hop we've recognized a concern with cultural artifacts which represent and form symbology that belong to poor suburbs, from the local social-historic territory and the language that is shared in there. Beyond that, the movement acts from the concern with local social reality so as to change the way of life that is in effect. To Hantaru

hip hop is about making a revolution where you live. It's as though you were an organization of kids who want to do something... we try to do something somehow. 
At the same time, the market is not a category that's absent from hip hop movement fights and action. Tiririca elucidates the importance of the movement's action in the poor suburbs to people's personal and professional actualization:

hip hop is not only the cultural part. Rather, it can promote work and income to folks who make hip hop and to a community - which is even more important, right? - and it can create jobs in these times of such a big crisis, that young people often have no job opportunity because market often requires a lot of things and there are few opportunities to start working. Today, Ksulo is a promoter of jobs, training and income through culture, today Ksulo develops the silkscreen printing project where young people learn to do graffiti; then, from graffiti he learns to get it into computers, working with Corel Draw, Photoshop. Once they've worked with Photoshop and Corel Draw, they move on to silkscreen boards and develop t-shirts, designs, and what they're really printing on designs is their own culture, right? And then they learn distribution and sale.

One hip hop movement peculiarity is its specific organization way. Unlike other social movements, whose organization practices create well defined structures, hip hop is near the phenomy category designed by Guerreiro Ramos (1981, p.152). That type of organization "[...] is part of the expression force which mobilizes a small group's or an isolated individual's creation activity". The author explains that results achieved through a phenomy's activity may be considered in terms of market. However, economic criteria are incidents in relation with their members' motivation. Developing a group's own culture coherently with the territory where it's made is the movement's motto. To PX,

hip hop is about culture, is about music and it brings in this range of knowledge because today we're faced with globalization out there, with all that information going on...

In a phenomy, the individual has a social conscience without giving up his own singularity. Another confluence point between the movement and a phenonomy is its occasional character, one that's more or less stable. In Porto Alegre, hip hop movement isn't made from a fixed organization structure, as Péia affirmed:

each poor suburb has an organizing way, its way of building, and that leads us to the word independence because if we are not independent, how are we going to organize Bom Jesus, we're going to organize the North Zone? It wouldn't work that way because dialogue, dialects are different within these communities.

However, hip hop events in Porto Alegre can gather groups from all parts of the city. What we can realize is that connections are made ad hoc, keeping each local space's peculiarities while contributing to the realization of a banal space in the city. Groups form a movement that is

independent in organization, but the idea is a unifying one, because the same proposal Ksulo has is present in other communities; it's the same proposal hip hop has for society, affirms $P X$.

That way of combining independence with articulate actions has also led to hip hop "movement" characterization's questioning. In that respect, Hantaru states his view as follows:

In fact, there's no movement. In music, there's always somebody who wants to take advantage on someone else, there's a movement when there has to be one, and also there isn't. Everybody wants their song playing on the radio, so groups even get along, but at the same time, there's this dispute. We even have causes in common, but it's like in politics, everybody wants the same thing, but they don't, it's hard to explain, I don't know...

Mano Oxi, as he reflects on the matter, says he prefers the expression young people in movement, or hip hop in movement and not hip hop movement. However, he stresses the large activity of groups in Brazil and realizes a disorganized way of organizing. 


\section{Final remarks}

Hip hop groups' wide objective scope allows us to assume that the movement is not formed only by specific groups and their connections, but by every individual that has a contact with any of the expressions which integrate their discourse action, so it goes beyond poor suburbs' limits, even though it is from the suburbs. Porto Alegre hip hop movement group discourse action operates in order to enable different organization connections and practices of a substantive character as opposed to the functional rationality that's dominant in market system's contemporaneity.

The music, or the rhyme, represents and affirms the identity of a large part of a young population who is marginalized, suburban and miscigenous, though mostly of African descent, in wider cultural spaces that previously didn't consider the ideas and practices those actors expressed (TRAPP, 2005). But, while it starts there, as we have seen from Hantaru's statements, it progresses into many other spaces, as we were able to see also from Mano Oxi's action as well as from all statements by members of groups we were able to contact.

The variety of fronts in which people of hip hop groups can perform reflects the diversity of organizations to which they articulate in Porto Alegre, mainly relating to education, politics and culture. These interactions provide most of the people involved in hip hop activities the opportunity to get information and access to resources they would not be able to, considering the conditions of living in those poor neighborhoods.

In what their inspiration from abroad matters, hip hop groups seem to perform the "critic-assimilative procedure", as they are influenced by the "foreign experience", yet born and fed in the ghettos, in the poor suburbs. Here, it is clear the characteristic of sociological reduction. Therefore, their action "doesn't imply isolationism or a romantic exalting of what is local, regional or national. It is, on the contrary, directed by an aspiration to universal, mediated, however, by what is local, regional or national" (GUERREIRO RAMOS, 1996, p.83-83, italics in the original).

Finally, in gratitude to the members of the groups who welcomed us and in honor to their fight, we retrieve to Guerreiro Ramos (1996, p.58) when he asserts that "when a social group puts between itself and the things around it an existence project" they enact a critical collective self conscience. This is path to self-actualizations is what seems to occur within hip hop groups from Porto Alegre researched. 


\section{References}

ANDRADE, Elaine Nunes de (Org.). Rap e educação, rap é educação. São Paulo: Summus, 1999.

ETCHICHURY, Carlos. BM monta acampamento na Vila Bom Jesus. Zero Hora.com, 29 ago. 2008. Disponível em: $<$ http://zerohora.clicrbs.com.br/zerohora/jsp/default.jsp?uf=1\&local=1\&section=Geral\&newsID=a2147820.xml>. Acesso em: 10 jan. 2009.

FAUSTINO, Oswaldo. Das ruas ao coração! In: ROCHA, Janaina; DOMENICH, Mirella; CASSEANO, Patrícia. Hip hop: a periferia grita. São Paulo: Fundação Perseu Abramo, pp.9-12, 2001.

FIALHO, Vânia A. Malagutti da Silva. Hip hop sul: um espaço televisivo de formação e atuação musical. 2003. Dissertação (Mestrado) $\square$ Programa de Pós-Graduação em Música, Instituto de Artes, Universidade Federal do Rio Grande do Sul, Porto Alegre, 2003.

GUERREIRO RAMOS, Alberto. A nova ciência das organizações: uma reconceituação da riqueza das nações. 1.ed. Rio de Janeiro: Ed. Fundação Getulio Vargas, 1981.

A redução sociológica. 3.ed. Rio de Janeiro: Ed. UFRJ, 1996.

LEÃO, Maria Aparecida da Silva Leão. O negro no mercado de trabalho pela cultura hip hop. Trabalho apresentado no XV Encontro Nacional de Estudos Populacionais, Caxambu, 2006. Disponível em: <http://www.abep.nepo.unicamp.br/encontro2006/docspdf/ABEP2006_371.pdf>. Acesso em: 15 fev. 2008.

MISOCZKY, Maria Ceci; FLORES, Rafael Kruter; GOULART, Sueli. Estudos organizacionais e movimentos sociais: 0 que sabemos? Para onde vamos? Porto Alegre, 2008. No prelo.

OUTHWAITE, William; BOTTOMORE, Tom (Org.) Dicionário do pensamento social do século XX. Rio de Janeiro: Jorge Zahar, 1996.

PAOLI, Maria Célia. As ciências sociais, os movimentos sociais e a questão de gênero. Novos Estudos Cebrap, n.31, pp.107-120, out. 1991.

PORTO ALEGRE. Lei oํ 10.378/2008, de 6 de fevereiro de 2008. Institui a Semana Municipal do Hip-Hop, a ser realizada anualmente, na segunda semana do mês de maio, que passa a integrar o Calendário Oficial de Eventos do Município de Porto Alegre, e dá outras providências. Porto Alegre, 2008. Disponível em: <http://www2.portoalegre.rs.gov.br/cgi-bin/nphbrs?s1=000029603.DOCN.\&l=20\&u=\%2Fnetahtml\%2Fsirel\%2

Fsimples.html\&p=1\&r=1\&f=G\&d=atos\&SECT1=TEXT>. Acesso em: 6 out. 2008.

RIBEIRO, Christian Carlos Rodrigues. Novas formas de vivências nas polis brasileiras? A ação transformadora da realidade urbana brasileira pelo movimento hip hop. Campinas, 2007. Trabalho apresentado em seminário. Disponível em: <http://www.usp.br/fau/eventos_sn/paisagemeparticipacao/movimentossociais/A02_hiphop.pdf>. Acesso em: 29 fev. 2008.

RIO GRANDE DO SUL. Lei no 13.043, de 30 de setembro de 2008. Institui a Semana Estadual do Hip-Hop, a ser realizada, anualmente, na segunda semana do mês de maio, e dá outras providências. Porto Alegre, 2008. Disponível em: <http://www.al.rs.gov.br/legis/M010/M0100099.ASP?Hid_Tipo=TEXTO\&Hid_TodasNormas=52092\&hTexto=\&Hid_IDNorm $\mathrm{a}=52092>$. Acesso em: 10 jan. 2009.

ROCHA, Janaína; DOMENICH, Mirella; CASSEANO, Patrícia. Hip hop: a periferia grita. São Paulo: Fundação Perseu Abramo, 2001.

TRAPP, Erin. The push and pull of hip hop: a social movement analysis. The American Behavioral Scientist, v.48, n.11, pp.1482-1495, July 2005.

WEBER, Max. Economia e sociedade. Brasília: Editora UNB, 1994.

\footnotetext{
1 When two or more rap groups gather, forming a group or an association, to perform social actions in their community (ROCHA;
} DOMENICH;CASSEANO, 2001) 